\title{
113. オフィス作業効率向上のための色温度変動照明の研究
}

一色温度変動照明による生理・心理的影響の評価一

井上学 野口公喜

（松下電工株式会社）
戴 倩穎 下村義弘 岩永光一 勝浦哲夫 (千葉大学)

\section{1 背景及び目的}

作業性の観点からオフィス照明の最適な色温度を経時的に主観評価を用いて求めたところ、自然光 に近似した変化を示すことが分かった（2001 年照明学会東京支部大会にて報告）。そこで今回は，前 回得られた色温度変動カーブによるアンビエント照明の制御と一般的な $5000 \mathrm{~K}$ 一定の照明要件とを比 較して心理・生理的な影響の違いを評価した。

\section{2 実験方法}

\section{1 被験者}

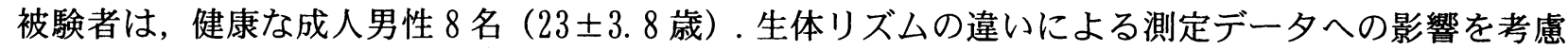
し, 実験 1 週間前から睡眠時間を 23:30〜06:30に統制し, 実験 2 日前からリストウォッチ型活動量計 により被験者の生活行動を確認した.

\section{2 実験環境}

実験室は, RGB の 40W 直管蛍光灯 3 本を 1 ユニットとし, ランプ前面には乳白パネルを取り付けた 照明器具 20 ユニットを天井に埋設した無空の部屋を使用した. また, 室温 $25 \pm 1{ }^{\circ} \mathrm{C}$, 相対湿度約 $50 \%$ であった.

\section{3 実験条件}

照明条件は, 机上面色温度が $5000 \mathrm{~K}$ 一定の条件と, 前回の実験により得られた色温度変動条件の 2 条件とした．机上面照度はいずれも $9001 \mathrm{x}$ 一定とした。

\section{4 評価方法}

被験者は測定日前日から実験室に宿泊とした. 測定日は 06:30に起床, 実験測定時間は 07:30〜12： 30 および $13: 30 \sim 17: 30$ の合計 9 時間, 休数時間は $06: 30 \sim 07: 30$ および $12: 30 〜 13: 30$ の合計 2 時間とした。休䕀時の照明条件は $5000 \mathrm{~K}, 2501 \mathrm{x}$ に設定した. 実験日の朝食, 昼食のメニューは条件間 で統一した. 測定は, 主観評価, 1 分間の天井照明器具の凝視, 直腸温, 血圧の測定を 10 分毎に行い, 脳波, 心拍変動, 加算タスクの測定を 1 時間毎に行った. 測定以外の時間は精神作業（ジグソーパズ ル）を行った。

\section{3 結果}

脳波において、 $\alpha$ 波帯域パワー密度は変動条件が有意に 高く $(\mathrm{p}<0.01), \beta$ 波帯域パワー密度は逆に変動条件が有意 に低かった $(p<0.01)$.

主観評価において、「眠気」 $(p<0.01)$, 「疲労感」 $(p<0.05)$ は変動条件で有意に低く,「集中力」 $(\mathrm{p}<0.10)$ は変動条件で 高い傾向にあった.

以上の結果より, 自然光の色温度の変化に近似した色温 度変動照明要件は一般的な $5000 \mathrm{~K}$ 一定の照明要件と比較し て, 疲労感や眠気, 精神的な緊張の軽減をもたらす効果の あることが示唆された。

Study on lighting with color temperature change during the day for

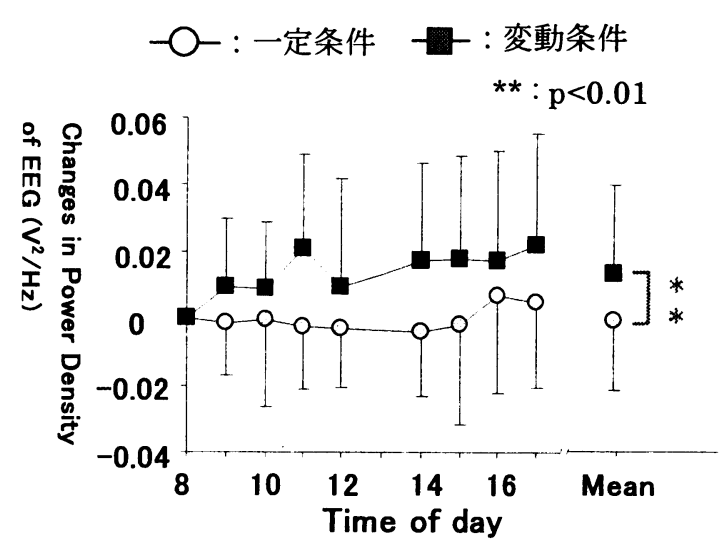

図 1. $\alpha$ 波帯域 $(8 \sim 13 \mathrm{~Hz})$ パワー密度 (開始時測定データからの変化) efficient office work

Manabu Inoue, Hiroki Noguchi, Seiei Tai, Yoshihiro Shimomura, Kouichi Iwanaga, Tetsuo Katsuura 